\begin{tabular}{l|l}
\hline SISTEMA \\
ELETRONIICO \\
DE REVISTAS \\
SER I UFPR
\end{tabular}

\title{
Entrevista com Magda Zanoni, realizada por Cleyton Gerhardt $^{1}$ em 03/10/2006
}

Magda Zanoni: a indisciplina multidisciplinar e apaixonada de uma incansável lutadora (in memoriam)

Em outubro de 2006, num final de tarde ainda frio da primavera gaúcha, tive a oportunidade de entrevistar por mais de duas horas Magda Zanoni, esta figura humana ao mesmo tempo tão forte, carismática e querida pelos amigos, mas que também sabia ser ácida e contundente em seus enfrentamentos e posicionamentos políticos. Estávamos então no centro de Porto Alegre numa sala que ela dividia com outros professores no segundo andar do Programa de Pós-Graduação em Desenvolvimento Rural da Universidade Federal do Rio Grande do Sul (PGDR), no qual viria a ser, três anos depois, também seu colega de casa e onde praticamente iniciara minha trajetória acadêmica ao final da década de 1990. À época começava meu trabalho de campo no doutorado, finalizado em 2008 no Programa de Pós-Graduação em Ciências Sociais em
Desenvolvimento, Agricultura e Sociedade (CPDA) pela Universidade Federal Rural do Rio de Janeiro. Até hoje guardo na lembrança certas passagens deste nosso longo encontro, quase que ouvindo internamente sua voz e ela falando sobre sua vinda, recém saída da adolescência, da então pequena cidade de Bento Gonçalves, interior "gringo" do Rio Grande do Sul, para a capital do estado no comecinho dos anos 1960. Havia conhecido Magda seis anos antes no próprio PGDR, quando iniciava em 2000 meu mestrado no programa, durante uma aula que ela havia dado para uma das disciplinas que então cursava sobre um tema bastante controvertido à época: os desdobramentos, sobretudo na Europa e particularmente na Inglaterra, da chamada "doença da vaca-louca" ou BSE (bovine spongiform encephalopathy). Como veria acontecer com outras pessoas muitas vezes a partir daí, a primeira impressão que ela causou na turma foi uma mistura de entusiasmo, inconformidade, engajamento e, acima de tudo, um conhecimento profundo sobre

\footnotetext{
${ }^{1}$ Doutor em Ciências Sociais pela Universidade Federal Rural do Rio de Janeiro (UFRRJ/CPDA). Atualmente é pesquisador e professor na Universidade Federal do Rio de Janeiro (UFRJ).
} 
o que dizia. Impetuosa, impulsiva, obstinada, persistente, companheira, afetuosa, por vezes teimosamente visceral. Mas se há uma expressão apropriada para definir Magda, como ela própria fala durante a entrevista, é que era "uma pessoa apaixonada". Apaixonada pela vida, pelo trabalho, pelos amigos, pela luta contra a injustiça e qualquer forma de violência e opressão. Alguém que não se acanhava em reafirmar sua "atração pela natureza, pelo mundo e pela sociedade", de ao mesmo tempo ficar "invocada" e "alegre" com alguma coisa que a mobilizava intelectual, política e afetivamente e mesmo de se deixar encantar por alguma "época maravilhosa" que viveu ao longo dos seus 73 anos.

Hoje pensando sobre as inúmeras experiências por que passou durante sua vida, creio que há dois fios condutores que se entrelaçam em seu relato e que apontam, primeiro, para a coerência ética e política por trás de sua trajetória e, segundo, para a sinceridade aguerrida com que buscou dar conta daquilo que, para usar novamente seus próprios termos, a "apaixonava". Por um lado, a eterna procura irrequieta por querer estar próxima ou ao lado da crítica social, estivesse ela: no movimento estudantil e seu engajamento na luta contra a ditadura que se implantara no país; na "organização troskista" da qual fazia parte até ser presa e depois exilada; na participação ativa (inclusive "ocupando terras") nas políticas de reforma agrária durante o governo de Salvador Allende e, pouco mais de um ano depois, após a Revolução dos Cravos, também em Portugal; na luta dos peasants franceses contra a expropriação de suas terras; na ampla e extensa rede de pesquisadores que ela ajudou a construir em torno dos conflitos ambientais no litoral do Paraná e sua crítica em relação à ação de grandes fazendeiros e grileiros na região e à atuação auto- ritária dos órgãos ambientais em relação aos pescadores e agricultores que lá viviam; na sua feroz denúncia sobre os resultados ecológicos e sociais da modernização da agricultura e cuja base técnica resultou, entre outros tantos efeitos danosos, no surgimento da doença da vaca louca na Europa nos anos 1990; no trabalho de articulação e organização de "ateliês", como ela chamou, durante o primeiro Fórum Social Mundial; na decisão que tomou após a eleição presidencial de 2002, quando achou que, depois de 32 anos na França e cerca de 20 deles vivendo quase em permanente ponte aérea entre os dois países, decidiu voltar de vez porque "tinha que colaborar diretamente aqui no Brasil”, vindo fazer parte do Ministério do Desenvolvimento Agrário e, como seu representante, a integrar a Comissão Técnica Nacional de Biossegurança (CTNBio); e, por fim, na sua incansável e repetida luta contra o câncer, que de tempos em tempos vinha desafiar sua teimosia em continuar vivendo e a contrariedade em aceitar se render à doença.

Já um segundo elemento formador de seu caráter diz respeito a uma espécie de rebeldia ou inconformidade intelectual consigo mesma, de estar pronta para, num dado momento, "tentar me questionar sobre tudo o que aprendi”, impertinência esta que a levou a "construir um caminho meio autodidata" e a transitar incansavelmente pelo desafio da interdisciplinaridade. Espécie de chave-mestra que lhe permitiu juntar seu ativismo político com a permanente preocupação em "contribuir com o conhecimento científico"; de ao mesmo tempo investir na "produção em pesquisa fundamental, mas que fosse próxima da realidade das pessoas". Em seu depoimento, diversas vezes o trânsito por diferentes áreas do conhecimento e o diálogo interdisciplinar aparece como algo central entre suas preocupações, 
e que vai desde: a paixão juvenil pela medicina; a capacidade de se "adaptar as novas circunstâncias" ao optar pelo curso em história natural; sua especialização em genética logo depois de formada; seu paralelo interesse pela "dimensão social" e que a levou a iniciar outra graduação no curso de ciências sociais (também interrompido pelo exílio); sua sólida aliança por cinco anos com o geógrafo Josué de Castro e o encontro duradouro com o economista Ignacy Sachs, de cuja síntese destas duas personalidades do mundo intelectual consolida seu vínculo (desde aí permanente) com o tema da agricultura; os 12 anos trabalhando no Laboratoire de Ecology Général et Appliquée; seu esforço em "juntar as peças" e, "pela agricultura" ou através dos "dois orientadores" que "arranjou" durante seu doutorado (um agrônomo e outro sociólogo), tentar conciliar seu "amor pela natureza, o aspecto ecológico, com o aspecto social"; a curiosidade que a levou a se "intrometer" em "questões de gênero" quando estudava as contradições da reforma agrária portuguesa após a Revolução dos Cravos; a proposição de diversos projetos de cooperação e pesquisa entre França e Brasil e seu empenho na construção de um programa interdisciplinar de pós-graduação na UFPR e cuja amplitude disciplinar incluía a participação de "sociólogos, antropólogos" e profissionais de áreas tão diversas como "engenharia alimentar, eletrificação rural, engenharia rural, economia rural, economia, agronomia e biologia marinha"; e por fim a "crítica à herança da ciência positivista", o questionamento "da ideia de especialização", o interesse constante pela "reflexão de caráter epistemológico" e o não acanhamento em se perguntar e refletir sobre o que "são as ciências hoje".

Mas antes de deixá-los com esta personagem, sem dúvida uma protagonista de sua própria história, ainda dois breves comentários sobre o contexto da entrevista e como organizei o texto que dela resultou. Sobre o contexto, na época a pesquisa que realizava para o doutorado ${ }^{1}$ dizia respeito às controvérsias entre pesquisadores e personalidades do mundo acadêmico sobre conflitos envolvendo áreas protegidas e populações locais de algum modo atingidas pela sua criação. Embora Magda já não estivesse mais naquele momento na linha de frente deste debate, decidi procurá-la devido à sua intensa participação nas décadas de 1980 e 1990 - e particularmente no que se refere à região do litoral do Paraná - na discussão sobre os desdobramentos provocados pela imposição de restrições ambientais e toda uma nova legislação e regras de conduta a uma série de grupos sociais que vivem em áreas tidas como "prioritárias" em termos ecológicos (indígenas, quilombolas, ribeirinhos, caiçaras etc.). Além disso, para que me interessasse em contatá-los, não bastava ser um cientista no sentido estrito, mas figuras que se destacaram pelo trânsito entre o campo da ciência e da ação política e intervenção direta, tendo se tornado intérpretes privilegiados e influentes atores no que se refere às políticas de criação/gestão de áreas protegidas; o que, certamente, era também o caso de Magda.

Por outro lado, como a biografia dos entrevistados constituía parte da própria história deste debate - cujo contexto se caracterizava pela exis-

\footnotetext{
${ }^{1}$ Para uma versão atualizada, ver GERHARDT, Cleyton. "Eu seria péssima pra estar na sua banca": pesquisadores e suas controvérsias sobre conflitos em áreas protegidas. Curitiba: Appris, 2016. Já sobre a trajetória das pessoas que entrevistei, ver a segunda parte de GERHARDT, Cleyton. Pesquisadores, populações locais e áreas protegidas: entre a instabilidade dos "lados" e a multiplicidade estrutural das "posições". Tese (Doutorado). Pós-Graduação em Ciências Sociais Aplicadas ao Mundo Rural, CPDA/UFRRJ. Rio de Janeiro: 2008.
} 
tência de um forte e por vezes beligerante e ácido dissenso -, estar com eles significava uma oportunidade de escutar histórias de vida de testemunhas vivas e participantes ativas de diversos episódios que marcaram não só a criação de áreas protegidas no país, mas todo o processo mais amplo de construção e percepção da problemática ambiental como "questão social relevante" e que levou, sobretudo a partir dos anos 1980, a sua progressiva institucionalização e elaboração de leis e estratégias específicas de preservação ambiental. Assim, como irão notar, na maior parte do seu depoimento Magda relata como foi sua trajetória pessoal e profissional, descrevendo eventos e experiências que teve ao longo de sua vida e quais caminhos trilhou até chegar na temática ambiental e seus desdobramentos sociais, políticos e operacionais.

Quanto ao texto em si, além de suprimir minha fala inicial, em que descrevo a pesquisa que vinha realizando, fiz apenas algumas modificações de forma e adequações ortográficas da língua falada para a escrita (adequação ao tempo verbal, ajuste de preposições e locuções prepositivas à norma culta, supressão de interjeições repetitivas etc.), estando os poucos trechos em que falo no meio da entrevista entre parêntesis e em itálico. Para melhor entendimento, inclui também, entre colchetes ou nota de rodapé, o significado de certas siglas e expressões, bem como o sobrenome das pessoas que são citadas ao longo da entrevista. Por fim, há algumas poucas palavras que não consegui traduzir devido à qualidade da gravação, sendo que uso [incompreensível...?] para indicá-las.

$$
* \quad * *
$$

Assim, Cleyton, a minha família é uma família de imigrantes mediterrâneos. Do lado da minha mãe eles vieram da Síria, sendo que antes minha mãe passou pelos EUA, chegando aqui no Brasil com oito anos, uma menina ainda junto com minha avó. Do outro lado, meus avós italianos vieram da região do Vêneto, na Itália, e aí foram viver em Bento Gonçalves. Nasci em Bento Gonçalves, estudei lá o primário, o secundário, fiz o científico, fiz a escola normal e também fui professora lá. Depois fui para Porto Alegre e o meu sonho era fazer Medicina. Gostava muito de ser médica, mas logo vi que não tinha condições, porque minha família... ah! houve um desentendimento muito grande na família. Meu pai faleceu quando eu tinha 10 anos e minha mãe ficou sem provimentos, não tinha condições de me financiar num curso de medicina. E você sabe, naquele tempo não havia bolsa, não havia nada disso.

Então deixei a ideia da medicina e tentei me adaptar as novas circunstâncias. Como havia feito o científico de uma certa maneira em escola normal, pude vir para cá fazer o vestibular e daí fui para a História Natural, que naquela época não era Biologia, pois tinha uma visão mais global da ciência. Para ter ideia, era um curso da Faculdade de Filosofia e durava quatro anos. Mas tinha todas as disciplinas das biológicas, citologia, botânica e também disciplinas da zoologia e da sistemática. Mas por outro lado, tinha disciplinas da petrologia, petrográfia, as histórias geológicas, geologia histórica, paleontologia, paleontografia. Então eu tive assim uma formação muito sólida, porque era um curso realmente muito bom, tive uma formação muito sólida nas ciências naturais. Bom, eu trabalhava durante a noite e também dava aula das quatro da tarde até sete da noite num curso vespertino lá na Vila São José, no bairro Partenon, para criança de vila, como se dizia na época. Aqueles que não podiam ser alfabetizados até sete anos iam para esse 
curso. Bom, aí trabalhei lá e foi o que me salvou para poder estudar, porque então eu estudava das oito às três da tarde e às quatro horas ia pra minha vila. Isso foi durante toda minha faculdade, fiz isso nos anos 60, 1961, 62, 63, 64 e me formei em 1964, continuei mais um ano em 65 e aí fiz uma especialização em genética.

Mas ao mesmo tempo fui sempre muito militante, acordei para a militância porque minha família era do PTB, que então era o partido Jango, do Brizola, do Getúlio, e digamos que eu me desenvolvi como criança e adolescente nesse meio que, naquela época, era um meio revolucionário para o que tinha de política no Brasil. Por exemplo, fiz minha primeira greve com 17 anos em Bento Gonçalves. Mas aí vim parar na universidade e na universidade evidentemente que fui para a militância, vim para cá e entrei no movimento estudantil e disso entrei num partido revolucionário que era crítico ao stalinismo, crítico à União Soviética, muito naquele caminho da revolução traída, que aquilo não era democracia socialista. A gente era um grupo pequeno, que até diziam aqui em Porto Alegre que cabia todo mundo num Volkswagen [risos]. Enfim, dentro de todos os grupos da época não fui de nenhuma associação cristã, entrei direto no marxismo e com o adendo do trotskismo, que era o que me dava a possibilidade de criticar tanto quem se dizia marxista como os regimes que diziam estar baseados nele.

E aí fiz a minha faculdade e quando terminei a história natural achei que tinha uma paixão muito grande pelas questões de sociedade, era assim muito motivada por trabalhar com os pobres, os sem nada nesse mundo. Daí fui fazer outro vestibular para ciências sociais, só que durante o curso obtive uma bolsa para ir para a França. Só que nesse momento também estava surgindo para mim a questão ecológica, via os movimentos que estavam acontecendo na França, Europa, nos EUA. Isso foi em 1968. Não peguei os movimentos de maio, porque fui para a França já mais no final do ano. Não estive lá em 68 também porque estava aqui nas barricadas brasileiras, mas lá vivi todo o período pós-68, cujas ideias ainda permanecem até hoje, muito como resultado de toda ebulição de maio de 68 , o movimento feminista, o movimento das minorias, o movimento ecológico e a crítica ao modelo desenvolvimentista e de todas as suas consequências.

Chegando lá comecei a estudar. Fui para fazer o mestrado na ecologia fundamental e científica, fiz esse mestrado e no meio tempo comecei a procurar um curso que me proporcionasse essa transição das ciências fundamentais, entre a ecologia fundamental para as ciências sociais. E me encontrei lá com o Josué de Castro, com quem a partir daí trabalhei durante cinco anos. Mas quando li "A geografia da fome", ainda aqui no Brasil, eu já tinha uma perspectiva dessa questão, porque em Porto Alegre fui também professora do Colégio Aplicação e do Colégio Israelita. E pensando hoje já tinha muito forte um viés social. Lembro que me perguntava: o que vou fazer com essa história natural num mundo de ditadura, completamente destroçado e com os movimentos sociais destroçados? Trabalhava com meus alunos no Colégio de Aplicação e organizei vários grupos de interesse político. Mas quando fui presa quando atuava no movimento estudantil, me expulsaram do Aplicação. Por isso fui para o Israelita, onde dava muita aula para alunos do então chamado científico e que iam fazer vestibular. Inclusive tem muitos aluno meu aqui em Porto Alegre que hoje são médicos, engenheiros etc. e que me encontram e me dizem: "mas que saudade dos nosso 
tempos"! Eu digo, assim, era uma época difícil, mas acho que tive um papel com essa gurizada aí.

Bom, mas fui para a França. Queria me encontrar lá com as grandes correntes políticas internacionais, queria viver as coisas de maio de 68 e a revolução de ideias que ela representou e coisa e tal. Depois de fazer esse mestrado em ecologia e trabalhar com Josué de Castro, me encontrei com Ignacy Sachs. Vi que era por aí que queria ir, me integrar ao seu grupo, porque ele tinha criado o primeiro mestrado em ciências do meio ambiente, ciências sociais e ciências do urbanismo. Só que esse pessoal estava além da minha universidade, então, depois que terminei esse segundo mestrado, fui para a Escola de Altos Estudos em Ciências Sociais, a École, e fiz com o Sachs. Correspondia ao mestrado daqui, que é um DEA, Diploma de Estudos Aprofundados em Ciências Sociais do Desenvolvimento, mas opção Ecodesenvolvimento. (Já existia isso...?) O Sachs já estava nisso junto com o Josué de Castro, já tinham um enrosco. Mas eles já estavam mais ligados com o terceiro mundo. As primeiras idéias de ecodesenvolvimento surgiram muito voltadas para os países da América Latina, para os países da Ásia, da África e depois mais tarde é que se consolidou essa temática e esses movimentos dentro dos países europeus, na França principalmente.

Bem, depois fui trabalhar com Josué de Castro e fiquei quase cinco anos lá na França, na universidade. Daí entrei para uma universidade chamada Charles Elicor. Fui assistente do professor principal e foi uma maravilha, porque a gente inventou cursos em plena época das contestações. A gente dava curso que falava da ecologia humana do terceiro mundo, sobre a guerra do Vietnã, a gente analisava a questão do efeito da dioxina, do efeito laranja sobre as florestas vietnamitas, sobre as populações, sobre os arrozais, sobre a saúde e por aí vai. Comecei a construir um caminho meio autodidata que não tinha muita coisa estruturada (por exemplo?). Por exemplo, participava dos seminários de antropologia com [Maurice] Godelier - porque ele estava tratando dessas questões, de relações de ecossistema e sociedade - e depois ia noutro sobre agricultura, onde eram tratadas questões do desenvolvimento rural. Então foi, digamos, naquele movimento maravilhoso de ideias que fui concebendo um caminho que não era um caminho clássico, disciplinar.

Fiz esse meu [incompreensível...?] e depois fui para o Chile. Fui para o Chile para ver se conseguia uma bolsa, porque achava que três anos na França já era bastante. No Chile, no primeiro ano foi tudo bem. Já no segundo ano fiquei lá durante o golpe contra o [Salvador] Allende, mas tive logo que sair depois do golpe. (mas exatamente o que você foi fazer no Chile?) Eu queria voltar para a América Latina, mas como fui condenada aqui no Brasil, não podia voltar para o Brasil. Fui exilada durante 14 anos. Mas enfim, fui para o Chile duas vezes, em 1972 providenciei tudo para ter uma bolsa e em 73 para ficar de vez. O resultado dessa bolsa nunca veio e em 73 fui para o Chile e fiz coisas maravilhosas lá, tirei umas 500 mil fotos, conheci muito da realidade chilena, trabalhava lá nas periferias. Bom, foi uma experiência única! Mas aí me peguei com o golpe e saí 10 dias depois do golpe, porque também fui trabalhar com a reforma agrária no Chile, fiz um estágio no INSIRA, que era um instituto de pesquisa e ao mesmo tempo um instituto de práticas novas da reforma agrária.

Mas, quando estava no Chile, daqui mandaram os nossos dossiês todos lá para a Embaixada do Brasil e também comunicaram a polícia, porque 
na época eu era de um grupo conhecido e tudo, participava aqui no movimento estudantil, fui presa e depois fui solta. (Mas fugiu ou foi expulsa do Chile?) Não, eu fui [incompreensível...?] oficialmente. Trabalhava na Secretaria de Educação e a maior parte do tempo estava com autorização. Mas depois do golpe fui condenada lá, porque aí o meu pessoal caiu todo, foi preso, foi torturado, e aí evidentemente falavam de quem estava fora, porque não iam falar de quem estava dentro, né? Só que depois do golpe consegui ser salva por um erro que a embaixada da França fez, porque já estava condenada aqui no Brasil, só que em vez de colocarem que era brasileira no passaporte, colocaram que eu era de nacionalidade francesa. Aí saí, só que ainda tive que passar pelo aeroporto do Rio de Janeiro, me dei conta de que foi uma loucura total, mas depois consegui um esquema.

Aí cheguei na França e disse: - bem, vou me instalar aqui e ficar quieta, vou trabalhar. Porque já estava trabalhando com o Josué, que, veja só, morreu dois dias depois que o Allende foi morto, ele era muito amigo do Allende, já estava doente e deve ter tido alguma influência. Enfim, como resultado disso tudo voltei para a França e comecei a dar minhas aulas. Só que aí já tinham feito 500 comitês por lá e aí entrei nos comitês, queria fazer parte de todos os comitês possíveis em defesa dos chilenos, era filme, era discussão, era conferência, era tudo. Bom, era 1973, o golpe no Allende foi um choque violentíssimo, achei que nunca mais ia acontecer nada no mundo e no ano seguinte estoura a Revolução dos Cravos em Portugal. Estava então trabalhando com meu diretor de laboratório - trabalhei em laboratório 12 anos, Laboratoire de Ecology Général et Appliquée -, sua especialidade era agricultura, porque era agrônomo, trabalhei com ele, fiz o meu mestrado lá e depois fui fazer meu doutorado. Mas quando estourou a Revolução dos Cravos esse professor me mandou para Portugal para fazer um curso lá no lugar dele, de dois meses, que no final durou muito mais.

Fui e fiz tudo o que podia fazer, ocupei terra, fiz cursos, até que me nomearam em Portugal no Instituto de Ciências Políticas e Sociais. Lá nós fizemos uma revolução. Antes era um instituto inteiramente fascista e, sabe, nós em assembleia geral expulsamos todos os velhos professores fascistas do tempo do Salazar e do Marcelo Caetano. Tomamos conta, fizemos barrar a estruturação global, ah!, foi uma maravilha. Disso fui então de novo para a reforma agrária. Porque nós fizemos escolas a serviço da reforma agrária. Enquanto os alunos de economia iam para as fábricas ocupadas em Portugal e faziam toda a contabilidade e a gestão com os trabalhadores, nós, a turma do rural, fomos para a reforma agrária trabalhar com os agricultores nas questões que eles precisavam. Bem, aí eu pensei: - quer saber de uma coisa, vou fazer minha tese de doutorado aqui. Naquele tempo já achava que não adiantava só estudar ecologia e os ecossistemas, como os homens se utilizavam e se apropriavam dos recursos etc. Até pela suas formas de organização social, pelas suas dinâmicas sociais, pelas suas políticas etc. e etc. Aí decidi estudar esse modelo novo, que era um modelo de ocupação de terra recente.

Fiz a tese durante todo esse processo e não foi fácil. Achei melhor criar um modelo que punha em relação os modos de exploração dos recursos naturais através da agricultura dentro de um novo contexto, que era de ocupação da terra e criação de novas unidades produtivas coletivas. Porque eu era muito..., gostava muito da natureza, eu era uma pessoa realmente apaixonada. Quer dizer, como é 
que posso conciliar a questão social com a questão da natureza e pela agricultura? Consegui juntar as peças porque a agricultura ainda é uma atividade que depende da natureza, do solo, da água e da energia solar. Então, acho que foi por aí que tentei conciliar naquela época o meu amor pela natureza, o aspecto ecológico, com o aspecto social. Arranjei dois orientadores, um era agrônomo e um era sociólogo lá na Sorbonne, e desses dois eu mesmo fiz a síntese. Porque toda minha vida foi de construir coisas que eram novas, de juntar os pedaços, porque cada um dos dois tinha 500 mil ideias e o contexto social e político permitia isso.

Nesse período fiquei indo e vindo de Portugal para França até terminar a tese. Escrevi um livro com um agrônomo português que também trabalhava comigo e fui lá na cooperativa entregar a tese a ele e levei várias garrafas de uma cachacinha. Mas quando cheguei lá foi uma decepção, estava tudo destruído. E de fato pude participar ainda no final da tese de parte do processo que levou a destruição das cooperativas. A minha tese foi no Alentejo, fiz em Monte Moro Novo, mas conviver com aquelas pessoas foi uma maravilha, foi um período que, quando cheguei de volta na França, não me conformava: - como pode a reforma agrária ser toda ela destruída? Devolveram o gado que tinha sido criado pelos trabalhadores, devolveram as casas, devolveram tudo, só não devolveram uma partezinha de cinco hectares que eles tinham pago com o dinheiro deles e foi que, digamos, o que sobrou.

Bom, aí voltei para a França. Já tinha escrito minha tese, ia e vinha, muito trabalho de campo com a mulheres. Me intrometia em todas essas questões, as questões culturais, questões de gênero, de escolha do que produzir a partir realmente desses novos dados da tese. Então apresentei minha tese, o Josué de Castro já tinha falecido, mas continuei na universidade, fiquei na Universidade, no departamento de geografia, onde introduzi toda essa questão ambiental. Depois resolveram que os estrangeiros não tinham mais carreira na universidade e eu era de uma carreira específica que se chamava Carreira de Professor Associado, que era só para os estrangeiros. Quando suspenderam, quando retiraram esse estatuto eu já tinha 17 anos de trabalho lá e daí fiz concurso nacional para a universidade francesa como se não tivesse dado nenhuma aula. Entrei por concurso e comecei a trabalhar.

Como já tinha na tese querido trabalhar e costurar essas questões de dinâmicas sociais, porque eram opções revolucionárias, de querer ocupar terras, ocupar máquinas em Portugal, queria analisar, por um lado, esse modelo de ocupação de terras dispondo dos meios de produção que o Estado concedeu, por outro, a dinâmica social que disso se desenvolvia do ponto de vista da educação, de relações de gênero etc. e, por outro ainda, que é como é que esse novo modelo lidava com a questão dos recursos naturais. E, bom, como essa região era muito influenciada pelo partido comunista, eles tinham as imagens da agricultura soviética, o que me fez ter de me confrontar com tudo isso, quer dizer, suas contradições. As mulheres, por exemplo, que tiveram que enfrentar a polícia nas maiores manifestações eram marginalizadas, não eram eleitas para nada dentro das cooperativas. Então o modelo era um modelo que evidentemente não tinha sido revolucionário em muitos aspectos, em muitos campos. Por exemplo, mantiveram o modelo clássico de uso da terra e dos meios de produção. E ali continuei fazendo entrevistas com as mulheres, com os homens, reconstituí cinco anos de rotações de culturas para ver como eles evoluíam nas técnicas. 
Bom, foi uma experiência magnífica e depois continuei na França, dando aula porque passei nesse concurso. Só que, como fui nomeada oficialmente na universidade, não era mais uma carreira de estrangeira. Entrei na universidade com o estatuto francês e nesse longo período do exílio tive que realmente investir lá, porque nós não tínhamos muita esperança que algo mudasse no Brasil. Tu vês, durou 20 e tantos anos, mas podia ter durado 40, como em Portugal e na Espanha. Daí investi lá na minha carreira e com os meus alunos. Acho que foi interessante porque começaram a surgir todos esses problemas ecológicos nas regiões de montanha, em regiões empobrecidas da França. Comecei... (telefone tocou, Magda atende - pausa). O que é que eu fiz, investi nessa mesma problemática que fui construindo e que me dava alegria, porque estava lidando com questões sociais, estava investigando uma área nova para mim que era o social, mas ligada a grandes questões de degradação ambiental que se expressavam pela agricultura, pela monocultura na região [incompreensível...?], na questão dos dejetos de animais, de bovinos e suínos na região da Bretanha.

Então fui a cada região que apresentava esse tipo de problemática e depois trazia para debater com os alunos. Também nós organizávamos estágios nas casas dos agricultores e chamávamos os agricultores da região para fazer conferências na academia. Foi uma época maravilhosa, aprendi a conhecer a França. Já tinha conhecido antes fazendo estágio de ecologia científica, fiz ecologia fundamental, fiz ecologia marítima, fiz ecologia de montanha, ecologia na agricultura, pois tive direito quando era bolsista, eles me levaram em tudo o que tinha de melhor na França na época. Quer dizer que, por um lado, tive a sólida formação em ecologia e, mais tarde, pude aprender muito na área da sociologia. Frequentei os melhores seminários que aconteciam por lá e disso fui compondo, juntando pedaços, sempre amarrando com a agricultura.

(Alguma ligação como movimento ecológico?) Sim, a gente tinha muita ligação com o movimento ecológico. Isso começou assim, na França o movimento pela ecologia começou muito pela ciência, pelas publicações científicas, o que quer dizer que quem começou a denunciar foi o pessoal da biologia. Realmente começou pela constatação da degradação do solo, do desaparecimento de espécies, era o que se via. E quem tratava dessas questões eram os biólogos, os ecólogos, e depois mais tardiamente entraram gente de outras áreas, sobretudo com o primeiro seminário que consolidou na universidade a relação sociedade/natureza como uma questão que precisava ser debatida de forma mais aprofundada, com o Maurice Godelier e com um agrônomo maravilhoso, Jacques Barreau, pesquisador do Museu Natural. Eu fui nesse seminário e daí para frente muita coisa aconteceu, com diversos movimentos se constituindo, grandes movimentos contra a energia nuclear, por exemplo, esse foi fortíssimo. E a juventude toda com quem eu dialogava pertencia a esses movimentos. Mesmo que depois de maio de 68 a contestação política tenha em parte diminuído, a contestação feminista e a contestação ecológica, que tinham suas raízes em maio de 68 , continuaram. Bom, e na universidade eu era conhecida, eles diziam que era uma excelente professora e que por isso tinha facilidade de transmitir minhas ideias para os alunos.

Aí, quando veio a anistia, fui anistiada em 79 , montei toda uma iniciativa de cooperação com o Brasil e que de lá pra cá continua dando seus frutos. Foi então que comecei a trabalhar com a região do 
litoral do Paraná, porque o Paraná tinha um governo progressista, enquanto que no Rio Grande do Sul ainda tinha os resquícios da ditadura no governo. Comecei a trabalhar no Paraná e fiz várias pesquisas com agricultura familiar, queria conhecer os modos de uso, os modos de apropriação dos recursos, dos sistemas agroflorestais muito específicos que existiam lá e que não eram divulgados. Aí veio a ideia de montar o doutorado, que puxei lá em Curitiba e junto com ele toda a reflexão que na França estava tendo. Uma reflexão de caráter epistemológico, de questionar o que são as ciências hoje, a ideia da especialização, de perguntar onde tinha se perdido a ideia de globalidade, de totalidade, que métodos e como trabalhar com toda complexidade da realidade etc.

Foi aí que entrei no tema das metodologias interdisciplinares e hoje estou aqui, nessa questão mais [incompreensível...?] dessa área. Por exemplo, as pesquisas na APA [área de preservação permanente] em Guaraqueçaba, no Paraná, tiveram início nessa cooperação França-Brasil, quando eu trouxe para cá uma série de pesquisadores que seguiam essa linha crítica e que de certo modo a partir daí mantiveram um contato permanente com os pesquisadores daqui, que até então não pensavam dessa maneira. Eles vinham de várias áreas, agronomia, tinha sociologia rural, economia etc. E daí a gente foi construindo essa interdisciplinaridade na pesquisa através de uma problemática que eu formulei quando vim sozinha lá para o Paraná. Fiquei muito, digamos, motivada, porque era uma área de preservação ambiental criada em 1982, essa da APA de Guaraqueçaba, onde de repente os pescadores, os agricultores começaram a ser perseguidos pelos órgãos ambientais. Só que nenhum estudo tinha sido desenvolvido, nenhuma pesquisa para se propor iniciativas de proteção em APAs, onde a proteção não é integral ${ }^{2}$.

Acho que esse foi um caso emblemático, um caso especial, porque foi o início das áreas de proteção, em 1982. Então começaram essas aberrações todas, os conflitos todos, que eu identifiquei porque tinha vindo para o Paraná antes de existir o doutorado, fiz uma pesquisa sobre sistemas agroflorestais na bracatinga, fiz outra pesquisa com um enfoque quase interdisciplinar com o Instituto Agronômico do Paraná, criamos uma equipe lá e trabalhamos em Rio Azul com o IAPAR. A situação foi evoluindo, já havia toda essa contestação no litoral [do Paraná] e ganhava força os movimentos denunciando a destruição da Mata Atlântica, isso tudo somado a realidade brasileira daquela década.

Resolvi então tentar entender as interações que haviam nesse contexto. Pescadores e agricultores que viviam da exploração dos recursos, mas que não eram "destruidores"; e se pareciam ser, era porque não tinham outra maneira de sobreviver, porque já sofriam com ameaças, violência, exploração, grilagem, sem ter apoio econômico nenhum. $\mathrm{E}$ a isso agora vinha se somar uma legislação ambiental que foi elaborada pelo Paulo Nogueira Neto e outros conservacionistas totalmente baseada na biologia e que simplesmente não considerava o conhecimento dos pescadores, o saber dos agricultores, suas regras comunitárias, seus sistemas de manejo que por anos foram adaptando ao micro-clima local etc.

\footnotetext{
${ }^{2}$ Referência às categorias do Sistema Nacional de Unidades de Conservação (SNUC) hoje chamadas unidades de conservação de "uso indireto" ou de "proteção integral", nas quais o uso da área é bastante restritivo, não sendo permitida a permanência de pessoas nela vivendo ou fazendo algum tipo de uso do meio natural.
} 
Até a gente entende que no início a proibição foi o modo de estancar a destruição feroz que existe nesse país, mas, ao mesmo tempo, isso não justifica reforçar o empobrecimento desses agricultores, desses pescadores, já marginalizados historicamente. E junto veio também toda a parafernália de leis, estudamos todas as leis. Criamos um grupo lá pela França e eu comecei a mandar meus alunos de lá, da pós-graduação, pra cá. Aí veio o Lovois [Miguel], que era daqui, aí depois veio a Magda Domingues, que fez uma tese sobre agricultura e pesca, a Laurence sobre o mangue, a Odile e o Bernard sobre o assoreamento da baía. Junto também entrou um pessoal da área da saúde, da medicina do Paraná e gente de áreas próximas também entraram com as questões de saúde. Enfim, procuramos cobrir todas as áreas e trabalhamos com métodos bem diversificados e sofisticados, alguns deles que nós já vínhamos usando lá na França e trouxemos e adaptamos para cá. Disso tudo saíram cinco teses durante esse período. De 1982 a 86 eu comecei a trabalhar com o pessoal do Brasil e aí em 87 veio o Lovois e depois começaram a vir os outros e no total mandei 18 alunos franceses e brasileiros também, porque o Lovois e a Tatiana Gerhardt eram brasileiros.

Nesse processo, começamos a trabalhar especificamente nessa área protegida tentando dar conta não só da questão mais teórica das relações entre sociedade e natureza, mas também da questão de que modelo de desenvolvimento nós queremos. É um modelo que preserva a natureza? É um modelo que diz preservar a natureza, mas faz isso em detrimento dos pescadores e agricultores, das populações tradicionais? Ou é um modelo de desenvolvimento diferente, que tenta dar conta de ambas as demandas, a demanda social e a ecológica, que tenta articular os dois sistemas, o sistema natural e o sistema social? Assim, baseado nessa possibilidade, de construir uma alternativa às políticas oficiais de desenvolvimento, procuramos por um lado investir na produção de conhecimento em pesquisa fundamental, mas que fosse próxima da realidade das pessoas e que vinha através das teses. Nossa ideia então era de que esse conhecimento forneceria dados de pesquisa que pudessem facilitar a construção de práticas de desenvolvimento locais.

Por exemplo, o que fazer com a pesca se os estoques de camarão se foram, se o mangue está todo sendo destruído? E você sabe que a grande riqueza lá vem das ostras, caranguejos e camarão. Ao mesmo tempo tinha toda essa questão da prática da queimada sendo feita numa região de Mata Atlântica, com os agricultores sendo acusados de destruir a mata porque faziam esse tipo de manejo tradicional. Só que nada se falava dos latifundiários que iam lá comprar terras, que grilavam as terras dos agricultores, exploravam o palmito e quem depois levava a culpa era alguns poucos sem força política e sem poder econômico nenhum e que tiravam um volume absurdamente menor. Pessoas, famílias, gerações delas que foram, na sua maioria, simplesmente abandonados pelo Estado por décadas e quando ele chegou, chegou com repressão, punição e violência. A gente estudava muito bem isso. Inclusive eu com o Randeau fizemos um texto que mais ou menos mostra essas dinâmicas, esses conflitos e que vem desde o começo do século, mas se aprofundam depois dos anos cinquenta até estourar nos oitenta com o pessoal do meio ambiente.

Nesse texto, sobretudo na última parte, também apresentamos todo o imbróglio problemático que veio com a presença na região da Fundação $\mathrm{O}$ Boticário, de ONGs como a SPVS [Sociedade de Pesquisa em Vida Selvagem] e daquelas empresas 
que em nome da proteção da natureza terminam por comprometer a reprodução social das pessoas que lá vivem. Nossas primeiras conclusões mais gerais vieram, portanto, depois de 10 anos de pesquisa. E se que cada turma nova sempre partia e se fundamentava em resultados precedentes de quem já havia estudado a região, questões novas sempre surgiam. E paralelamente a essa problemática de pesquisa que veio junto com os alunos que vieram da França, desenvolvemos aqui um doutorado e criamos uma turma de doutorado para estudar especificamente a APA. Também fizemos um projeto de desenvolvimento com os dados das pesquisas que produzíamos e conseguimos construir com os pequenos agricultores uma unidade de transformação dos produtos da floresta, da banana e do palmito. Também desse esforço, principalmente através das teses sobre a pesca e sobre mangue e que indicaram os melhores lugares e as melhores práticas de cultivo, conseguimos construir uma unidade de seleção de ostras que não são mais as ostras do mangue, mas que são ostras de cultivo.

E nessas duas unidades a gente sempre tentou fazer com que a ruptura técnica fosse a menor possível. Como no caso das ostras, pois passar de uma prática de coleta de ostras do mangue para o cultivo de ostras foi uma transição branda e hoje eles cultivam a ostra e não predam mais. Porque antes a predação acontecia muito porque não tinham o que comer e no caso da floresta é a mesma forma. Só que com o tempo eles começaram a fazer o plantio do palmito através da seleção de sementes, avaliação da [incompreensível...?] na semente, tudo isso através de pesquisa. Tinha também um engenheiro florestal na turma dos franceses que trabalhou com os agricultores e aí conseguimos produzir o palmito de plantação no meio da floresta. E como a cultura do palmito, a banana é uma banana ecológica, sem agrotóxico, natural. Enfim, baseados numa outra ideia de desenvolvimento a gente atacou várias frentes.

(há vários grupos com interesse nesse lugar, inclusive a própria divisão de pesquisa que vocês faziam parte, como foi essa dinâmica?) Não foi uma dinâmica fácil, porque nós da França nos aliamos ao pessoal da Universidade Federal do Paraná. No começo havia até uma atitude meio nacionalista de alguns: - afinal, o que é que esses franceses vieram fazer aqui? Mas eu era brasileira, né? E depois nós conversamos muito com os técnicos locais, foi bem interessante essa relação com os técnicos locais do IBAMA, da Emater, do ITCF, que agora se chama IAPAR. Então houve uma evolução nos conflitos e nas nossas relações com eles. Também fizemos um pouco também o papel de mediadores, porque no início eles batiam nos agricultores, batiam nos pescadores, teve caso quase que de tortura. (Física?) É, é o que eu chamaria de tortura física, porque quebrar a falange da mão de um agricultor que arrancou um palmito, colocar o agricultor num formigueiro porque ele arrancou um palmito, amarrar um bugio ao redor do pescoço de um deles porque comeu bugio do mato - sendo que nunca faltou bugio, lá é um alimento essa caça, um costume deles - e o obrigar a desfilar nu no vilarejo para depois largar ele lá na periferia de Curitiba, sem roupa e sem nada? Essa era a prática da polícia florestal para proteger a APA, a natureza e a Mata Atlântica.

Eu tenho uns artigos que acho que valeria a pena tu leres, um do Claude Raynaut, que foi um dos últimos que nós mandamos para um congresso internacional de antropologia em Roma e que vai sair sob forma de livro nos EUA. Sim, tem toda a produção sobre como fazer pesquisa numa área de 
proteção ambiental, como essa área tem que ser desenvolvida e quais critérios usar para se formular uma legislação, uma lei de proteção fundamentada não só no conhecimento acadêmico vindo da biologia, mas que venha também do que sabe, vive e pratica a população nativa. Proteção da Mata Atlântica, sim! Proteção do estuário, sim! Mas, antes de pensar essa tal proteção, e como vive as pessoas que lá estão já a várias décadas e até mais de centena de anos? Digo isso porque nós teríamos que ter instituído uma APA onde a proteção seria feita a partir dos agricultores e pescadores locais e não em detrimento deles. Enfim, Cleyton, disso foram surgindo ideias e perguntas sobre o que seria uma gestão democrática, o que seria um conselho comunitário, o que ambos significam afinal? E essa problemática foi se desenvolvendo a tal ponto que as questões sociais foram todas aparecendo juntamente com as questões ligadas à garantia da reprodução do meio natural, reflexão essa em que os dois projetos [produção de palmito e cultivo de ostras] tiveram um papel muito importante. E como resultado o doutorado obteve a carta da UNESCO de desenvolvimento sustentável, que é um selo de qualidade. Foi assim, realmente um impacto. Apresentei na UNESCO, na conferência de educação, o projeto de desenvolvimento que nós fizemos no litoral do Paraná baseados nos resultados de pesquisa e ele obteve o prêmio da UNESCO de tecnologia social.

Mas aí no final de tudo isso ou lá pelas tantas aparece a SPVS, Sociedade de Proteção da Vida Selvagem. Ela aparece no meio do processo e com muito dinheiro, porque é ligada à $\mathrm{TNC}$, The $\mathrm{Na}$ ture Conservance, cuja sede fica nos EUA. Bem, as campanhas deles eram do tipo "vamos salvar o mico leão dourado", era estritamente de proteção a fauna e a flora e, claro, logo se criou uma certa rivalidade da parte deles conosco, sobretudo porque nós estávamos tirando uma área protegida do que eles achavam que era e sua "verdadeira vocação". Éramos mesmo chamados de "os desenvolvimentistas", como se a gente fosse transformar tudo numa monocultura de trigo. Então, a partir daí, além dos conflitos que nós tínhamos com os técnicos locais, além disso, passamos a ter pela frente a SPVS e, posteriormente, [a Fundação] O Boticário, que comprou uma terra enorme para fazer negócio com sequestro de carbono. Não, minto, a SPVS é que comprou para sequestro de carbono e O Boticário comprou outra terra importante para fazer educação ambiental, sobretudo fazer capacitação de adultos com uma escola de formação em botânica.

Também analisamos essa entrada nova desses atores sociais, que se dizem protetores da natureza, mas com certos objetivos não muito claros, com uma tese que nós orientamos, o Claude Raynaut e eu, que até foi a segunda tese premiada pela ANPPAS [Associação Nacional de Pós-Graduação e Pesquisa em Ambiente e Sociedade], foi o segundo prêmio da ANPPAS nesse ano, a tese da Cristina Teixeira.

Então fomos elaborando e readequando o trabalho, porque o início veio com todas as teses dos franceses e depois fomos integrando os daqui, mas sempre em forma de programa interdisciplinar e que exigia um esforço, uma construção coletiva em que íamos integrando as novas questões que surgiam. Com esse enriquecimento, se tomarmos a nossa problemática dos anos 90 e comparar com agora, ela foi mudando. Há uma linha de evolução dessa problemática e que, na medida em que vão se desvendando os conflitos, as questões, as dinâmicas locais, vão se apresentando novas questões e novos desafios de como tratá-las não só analiticamente, mas também pensando uma intervenção prática. No 
aspecto técnico, por exemplo no desenvolvimento da agrofloresta e da banana, nós descobrimos um sistema de associação de culturas entre banana e palmito que ninguém sabe de onde teve origem, mas todos que vivem lá fazem, eles fazem com a banana e o palmito no mato. Daí a gente introduziu, qual era o recuso raro? O palmito, então nós mapeamos várias áreas, fizemos a seleção de sementes no solo, replicamos, fizemos os potes, depois eles fizeram o plantio no mato, na floresta e nós depois mapeamos. E cinco anos depois eles estavam colhendo o palmito plantado e esse palmito depois é o que entrava na fábrica para transformação e conserva, porque tinha que ter o certificado.

Mas foi muito interessante esse processo, fiz todo esse trabalho com a Pró-Reitoria de Extensão da UFPR. Ela é uma [incompreensível...?] excelente, excelente, com uma grande noção da extensão e aí ela tomava conta lá do cotidiano e eu vinha regularmente para o Brasil e meus alunos foram formando parcerias e trocas com os alunos brasileiros da agronomia, da economia da UFPR. Nós fomos direcionando os cursos da federal para responderem as questões da nossa problemática e daí foi interessante porque os alunos da agronomia, economia etc., que participaram de seis meses a um ano do projeto, eles receberam um certificados de estágio pela Universidade de Paris e outro pela Federal do Paraná e no fim fiz uma enquete e perguntei para eles como se sentiam como agrônomos depois desse estágio. E muito responderam que não seriam os mesmo profissionais se eles não tivessem passado por lá, porque conviveram com os conflitos sociais, conviveram com sociólogos, antropólogos. Também na universidade os professores que se trabalhavam com eletrificação rural, engenharia rural, economia rural e biologia marinha entraram no projeto para responder as questões que vinham da pesquisa dos alunos. Então, por exemplo, começou a aparecer água contaminada na fábrica de banana e não havia jeito de descobrir de onde vinha. Aí começaram a achar que eram as pessoas que estavam fazendo as suas necessidades no mato, no rio etc. Só que o pessoal da saúde foi lá, fez uma pesquisa grande, e foram encontrar contaminação através dos mamíferos do mato que faziam suas necessidades pelo rio, na parte de cima do rio, e aquilo vinha na água da fonte. Então eles montaram todo um sistema de filtragem para poder ter o visto da Anvisa e assim poder continuar produzindo. Depois teve o problema do secador que consumia muita energia e para eles lá era um gasto grande. Primeiro nós tentamos a energia solar, mas não deu certo, porque é muita umidade também e aí foi interessante porque veio a turma da eletrificação rural, engenharia rural e disseram: - não, nós é que fizemos esse secador e então nós vamos ter que modificar! E fizeram outro. Ainda aumentaram o secador e diminuíram em 20\% o consumo de energia. Então tudo era pesquisa, umas tinham um caráter mais fundamental, analítico, já outras eram bastante técnicas, específicas.

Outra consequência benéfica para a universidade é que criaram disciplinas a partir do projeto. Então na engenharia rural eles inscreveram o projeto como uma disciplina com toda a discussão sobre a realidade local. E na biologia marinha, bom, os pescadores não sabiam como era uma ostra. Então fizeram um curso para os pescadores sobre a morfologia da ostra, sobre a reprodução e tal junto com os alunos. E na faculdade, a partir dessa experiência criaram um curso na biologia marinha que não existia. Também isso aconteceu do lado da agricultura, porque introduziram nos cursos de economia agrícola e de engenharia rural um espaço 
voltado para pensar a realidade local, todas as práticas de confecção da banana etc. Veio uma aluna minha lá da França que fez um curso de engenharia alimentar, ela levava os agricultores, os produtores da região para fazer provas com as bananas, muito açúcar, pouco açúcar, cor etc. Até que hoje eles têm um programa de comércio justo com a Suíça, em Zurique, vendem a banana no comércio justo, mas não abandonaram o local, continuam alimentando o comércio local.

(e como é que ficou esse tipo de postura dos técnicos?) Eles foram evoluindo também num contexto mais global, começaram a surgir questões sobre a proteção, sobre a conservação, muito porque acho pelo fato de estarem em contato conosco. E os alunos franceses que vieram da França ficaram todos lá, morando na ilha, morando no mato, não eram alunos de cidade. Uns compraram uma casinha, outros alugaram uma casa, então eles criaram um tipo diferente de relação com a população, faziam festas com os técnicos e convidavam todo mundo e nisso acho que os técnicos foram aos poucos também se integrando. E mais importante, na discussão das ideias eles foram entendendo muitas coisas que ignoravam e também criando uma maior sensibilidade para certas questões. Para ter uma ideia, o Ibama, que no início não podia nos ver na frente, hoje dá bolsa para os alunos e dá graças a Deus que os alunos fazem pesquisa lá. Então, para tu veres como foi um projeto excepcional.

(E vocêficou indo e vindo da França?) Fiquei indo e vindo, cada aluno que veio eu vinha junto e instalava ele aqui, apresentava todo mundo na universidade, os organismos de Estado etc. E também os dois governos apoiaram muito, a França dava as bolsas e o governo dava o correspondente, então se criou uma cooperação bem articulada e bem quista [aqui Magda dá um sorriso amplo e aberto], isso mesmo no campo das relações pessoais [risadas], houve até casamentos, uns tão na França, outros tão aqui no Brasil. Então para tu veres que isso aí tem uma história que foi de laços, de laços sociais e de laços de amizade. (O curso que existe agora lá, interdisciplinar, foi fruto disso) O doutorado. É, veio depois do começo de nossa pesquisa na APA, eu e Lovois que começamos em 1987. Em 88 o Lovois foi para lá, ficou seis meses e voltou em 89 com a bolsa já para fazer a tese lá. Depois foi Marie Dominique, a Laurence e o Tcherry, que eram companheiros, e o Bernard. Depois foi um cara para trabalhar com a água sobre os esgotos e encanações, o Dominique, que depois foi para a pesca; veio o Felipe depois a Celine depois uma menina lá muito interessante que falava sobre políticas ambientais, se chama Alma. E assim foi indo.

(E como funcionava o curso, digo assim, em termos de organização) O curso foi criado dentro da universidade pelo reitor. Como queríamos um curso interdisciplinar, não queríamos a predominância de nenhuma disciplina, o curso foi posto dentro da Pró-Reitoria e não tem nenhum departamento predominante, específico, todo mundo dos departamentos dá aula lá dentro, entendeu? (E como é que seguiu?) Bom, agora estamos fazendo um livro lá no Paraná com essa experiência. E teve o título honoris causa, que eu ganhei. Mas acho assim, não devia ter sido eu, devia ter sido todo mundo, só que como não pode ser todo o grupo, eu e o Raynaut recebemos o título de doutores honoris causa da Universidade Federal do Paraná por todo esse trabalho. Sabe, acho que é interessante, porque não dou bola para títulos, fico feliz mais pelo reconhecimento de uma equipe, quer dizer, do que é que nessa equipe no fundo fez diferença. No início não se tinha interesse nenhum, 
mas com o tempo com ela se criou muita coisa, porque, olha, esse doutorado permitiu a realização de um projeto França-Brasil de [incompreensível...?] de quatro anos, mais um convênio CNRS com o CNPQ, mais um convênio da região da Aquitânia na França, mais idas e vindas para colóquios e congressos, mais publicações, livros, tu entendes?

Então teve uma preocupação também em termos de fazer a nossa ciência, de contribuir com o conhecimento científico. Foi aí que me surgiu essa ideia que hoje em dia estou muito invocada e investida dela, que é pensar o que é a pesquisa e o pesquisador-cidadão? Dessa pergunta vem todo um seminário que estou querendo organizar e que se chama: "Novas Modalidades de Pesquisa no Meio Rural". Pesquisa essa feita a partir de uma, digamos, de um outro enfoque, de uma outra metodologia que admita que os nossos entrevistados, que a população local, que eles são tão pesquisadores quanto nós. É nesse tipo de..., nessa nova ciência, essa nova maneira de fazer ciência é que estou interessada. Tu vês que é engraçado, né? Pensando na relação sociedade- natureza, primeiro fui para a ecologia, depois para as ciências sociais, depois a junção dos dois por motivação pessoal, por atração pela natureza e pelo mundo, pela sociedade, depois pelos recursos da agricultura na França e finalmente aqui no Brasil a partir de 87 , quando ganha força o enfoque interdisciplinar. Aí vieram os projetos do IAPAR, em primeiro lugar, depois a pesquisa com a bracatinga, depois o do Rio Azul, depois esse da APA e finalmente o doutorado.

Nós fomos para lá em 83 e estou lá até hoje, bom, hoje menos implicada, porque acho que eles já fazem o caminho deles sozinho, não nos precisam mais. Agora estou muito partindo de toda essa discussão sobre a ciência, da crítica à herança da ciência positivista do século XIX, da ideia de que a ciência leva diretamente ao progresso e etc. Eu fui evoluindo e também não sei te dizer, acho que foi por aí que veio a questão da interdisciplinaridade como uma maneira fundamental, uma metodologia essencial para ter um enfoque alternativo sobre a realidade complexa das interações entre os atores e entre eles e o meio onde vivem. Pra mim só através da interdisciplinaridade é que se pode revolucionar a redução disciplinar que cada vez mais vive a ciência. Aí é que aparecem de modo claro as questões que estão por trás da própria ideia de ciência, da ideia, ou melhor, do pressuposto de que ela é necessariamente necessária à humanidade. Por que nós recortamos a realidade em sociologia, em antropologia, em economia, em direito etc.? Esse cacoete vem de todo um movimento que inicia no século XIX, mas que chegou ao século XX e que na metade do século XX começou a ser contestado pela própria incapacidade de avaliar criticamente o que a gente chama de "modelos de desenvolvimento", de observar e avaliar processos e transformações sociais e a exploração dos recursos naturais de maneira articulada.

Além disso, e esse é um outro problema dentro da ciências estabelecida, se foi criando uma espécie de repulsa geral de qualquer discussão que implique tomar um posicionamento político explícito sobre algo considerado "científico". Ora, meu caro, já que o que dela sai interfere diretamente na vida das pessoas, mais do que nunca a gente precisa politizar a ciência e não o contrário, né? Daí comecei a me interessar pela ciência, sobretudo por essa modalidade de ciência crítica e interdisciplinar. E agora estou na CTNBio [Comissão Técnica Nacional de Biossegurança]. Estou na CTNBio também porque fui bióloga, mas não me considero mais bióloga 
hoje, porque passou muito tempo, as coisas mudaram, a ciência mudou. Só que o raciocínio da ecologia que fiz na França e os três anos de ecologia fundamental me acrescentaram à análise social. E isso vem desde o Fórum Social Mundial aqui em Porto Alegre, quando organizei aquele atelier sobre a ciência (Ah! sim, no Fórum que vocês trouxeram a Danielle Miterrand, isso?) Sim. E agora estou querendo lançar com um grupo, porque, e isso é importante e queria que tu dissesse, eu não trabalho sozinha, viu! Porque acho que o coletivo é que enriquece. Sim, dá muito trabalho, muito conflito, mas acho que o conflito também educa, principalmente em termos de olhar para nossa própria realidade pessoal, para nossos narcisismos, sabe! E agora nós estamos tentando fazer entre alguns pesquisadores um grupo de associações e de movimentos sociais, um Observatório Nacional da Biossegurança, por uma ciência cidadã que inclua ciências sociais e ciências naturais, desde a pesquisa biomolecular, gens, moléculas etc. até questões de caráter sociológico e antropológico.

(Existe um hiato aí, quando você veio de vez para o Brasil, como foi?) Bom, tive muita dificuldade na minha vinda para o Brasil. Sim, fazia lá na França muita coisa com o Brasil e estava assim, como é que vou dizer, investi muito em pessoas que me acompanharam, como o Raynaut. Eu e o Raynaut fomos os dois mosqueteiros e viemos permanentemente por 12 anos seguidos para cá, nunca poupamos esforços, inclusive até nos prejudicando lá, porque evidentemente o meu emprego era lá. Mas ao mesmo tempo publiquei muita coisa que eles não podem dizer o contrário, sem contar que impliquei muito a França nisso também. Mandar mais de 20 alunos para cá! E isso até hoje, como no caso de um outro projeto em que vieram a Natalie, a Celine, a Cecilia, um projeto de cooperação com jovens que não tinham muitas perspectivas por lá ou que estavam meio desanimados. E nessa turma tem todo um grupo de jovens que quer vir para o terceiro mundo e que tem a esperança de contribuir de algum modo. São esses os que vêm.

Então nessa dinâmica toda, quer dizer, terminei vindo para cá. Dei as minhas aulas todas lá, fiquei dois anos no Centro Nacional da Pesquisa Científica, em laboratório, mas aí veio a eleição de 2002 e eu achei que já estava há 32 anos na França e que tinha que colaborar diretamente aqui no Brasil. E fiz a minha volta. E aí por razões de temática eu podia ir para dois ministérios, ou meio ambiente ou desenvolvimento agrário, porque minha área podia ser qualquer uma das duas. O problema é que tinha pouco contato com o pessoal do Ministério do Meio Ambiente e tinha mais contatos no Desenvolvimento Agrário. Só que na verdade eu fiquei no meio do caminho, quer dizer, trabalhei muito nos dois lados, onde podia e onde aparecesse a oportunidade.

Porque também, Cleyton, queria fazer a experiência de sair do meio universitário e tentar me questionar sobre se tudo o que aprendi na França, se tudo o que elaborei, ou se as minhas experiências poderiam ser úteis na prática num nível executivo. Se eu podia ter um papel dentro das instâncias de poder político propriamente dito. Tenho as minhas dúvidas se realmente essas ligações foram proveitosas como eu esperava, mas bem, fiz minha experiência de três anos e organizei seminários, fiz aquilo que um pesquisador tem competência para fazer e tentei avançar em algumas ideias. Uma delas foi poder abrir o Observatório Nacional da Biossegurança e atuar na CTNBio, onde estou ainda. E aí, no caso da CTNBio, sinto um pouco que tive que voltar atrás sem voltar atrás, porque lá só 
tem biólogo e geneticista e eu não entendia mais ou quase nada quando começavam a discutir a miudeza mais técnica de cada área. Minha entrada se deu pela discussão da própria ciência, de por ela em questão: que ciência é essa que se pratica? Qual é a ideologia por trás e as representações que informam quem faz ciência? E vou escrever sobre isso. Então, nessa última etapa de evolução de meus interesses sigo com minha motivação de trabalhar sobre essas questões de ciência, que não significa trabalhar com a ciência que se faz na engenharia, por exemplo, mas sim de pensar sobre as concepções de ciência que estão por trás da discussão sobre biodiversidade, sobre biotecnologia e sobre áreas protegidas.

(Sobre seu papel dentro da CTNBio, queria que você falasse um pouquinho dessa experiência nesse ambiente) Bom, houve Cleyton - e tu conhece bem a história aqui da soja que se liberou por medidas provisórias e que foi clandestina no início -, mas houve nessa nova $1 \mathrm{ei}^{3}$ mudanças que considero que são um retrocesso muito grande. Perdemos grande parte do que havíamos proposto e mesmo que a Câmara [dos Deputados] tenha votado uma lei razoável, o Senado, com os grandes senadores da soja, voltaram atrás e puseram outros elementos que não eram os mais progressistas. Mas assim mesmo essa lei, nas nossas mãos, tem servido um pouco na questão da biossegurança. Por que ela indica o quanto de cientistas é escolhido pelos ministérios para a comissão [incompreensível...? provavelmente a própria CTNBio].

A lei criou essa comissão e essa comissão engloba então os 12 cientistas, que vem do meio acadêmico, mais os representantes dos ministé- rios, dos quais nós somos uma minoria. Nela estão os ministérios do meio ambiente, da pesca e do desenvolvimento agrário. Os outros oito são do outro lado, quer dizer, são pró-biotecnologia, nem a saúde não está conosco. Mas uma novidade total tem sido a participação dos movimentos sociais, tem um representante da saúde do trabalhador, um do IDEC [Instituto Brasileiro de Defesa do Consumidor], um da agricultura familiar, que é o Fabio Dal Soglio, daqui do PGDR, todos com seus suplentes, um representante dos movimentos sociais e ambientais e um representante dos movimentos sociais ligados à saúde. Isso não existia antes. Então as coincidências se deram e nós nos entendemos bem com esses representantes dos movimentos, embora sejamos minoritários em termos de ministérios. E os 12 cientistas positivistas se dão muito bem com os ministérios da Indústria e Comércio, da Agricultura, da Ciência e Tecnologia e etc.

Mas nossa entrada provocou uma verdadeira rebordosa lá dentro, porque eles não estavam acostumados a sofrer contestações, a serem confrontados. Olha, no começo foi muito bonito, a gente não deixava passar nada e chegou num certo ponto em que o conflito de interesses atingiu um extremo tal em que tinha pesquisador da Monsanto ou que recebia dinheiro ou apoio da Monsanto votando nos processos em que a Monsanto tinha interesse direto. Aí esse termo de referência [que aqui provavelmente impedia tal prática pelos integrantes da CTNBio] devia ter sido assinado na posse, no dia 27 de dezembro do ano passado, só que passaram cinco meses e o diretor da CTNBio não fazia assinar. Aí os movimentos sociais, como aqueles que

\footnotetext{
${ }^{3}$ Provavelmente Magda se refere aqui à chamada Lei de Biossegurança, Lei Nº11.105, aprovada em março de 2005 durante gestão do presidente Luis Inácio Lula da Silva e que estabelece normas de segurança, mecanismos de fiscalização e procedimentos para liberação de organismos geneticamente modificados, os OGMs.
} 
tu conheces, fizeram uma pressão, denunciaram para o Ministério Público Federal e o Ministério Público interveio através de uma Procuradora Geral da República. E daí foi uma revolução lá dentro, foi muita indisposição contra essa mulher, a ponto de dizer que nós estávamos vivendo um novo 64, que isso estava parecendo o envio da polícia de Brasília para as assembleias de professores e alunos da USP em São Paulo, que era policiamento, que aquela mulher não tinha nada que fazer lá.

O que aconteceu foi que o grande corpo da nobreza científica se revoltou contra a política. Lá dentro da comissão, a cada cinco minutos se repete que ela seria uma comissão técnica que não tem nada a ver com política. Bem, daí as minhas intervenções na mesa foram sempre em termos científicos, quer dizer, em termos de crítica da ciência, de apontar o que o discurso técnico esconde e fica envergonhado quando é pego com a boca na botija, que pode ser o dinheiro, por exemplo, mas também a vaidade, a falsidade, o patrimonialismo, o moralismo, o prazer doentio pelo prestígio, pelo holofote. E eles não me respondem, não me respondem. Até já disseram que queriam que eu me retirasse da comissão, que os mais ideologizados - que para eles são eu, o [Rubens] Nodari do ministério do meio ambiente e os representantes dos movimentos, mas sobretudo nós dois - se retirassem. Mas a luta continua, porque nós fomos na Casa Civil e ganhamos uma grande batalha. Não foi ganho total, mas nos juntamos com a composição do governo brasileiro na Conferência das Nações Unidas que aconteceu no Paraná e contribuímos com o consenso que se estabeleceu, que se consolidou com a recusa dos gens terminators.

(só mais duas ou três questões pontuais; como você avalia o processo de constituição das áreas protegidas no Brasil?) Acho que isso é um movimento mundial, temos os parques em todos os países praticamente, parques naturais nacionais que não admitem a presença humana. E aqui temos as também as chamadas Reservas de Biosfera, as APAs, Áreas de Proteção Ambiental, e ultimamente tem crescido as RPPNs, Reserva Privada de Proteção da Natureza. Mas eu acho que tudo isso merece uma análise das contradições por trás dessa problemática. Porque se tu fores ver bem - e foi esse todo o problema de Guaraqueçaba que a gente analisou -, se construiu uma APA cuja proteção se resumia a reprimir a população local, em proteger a biodiversidade em detrimento das populações locais. Não estou dizendo que não há a necessidade de uma proteção, só que do jeito como ela foi imposta não foi o melhor jeito, porque a reflexão sobre suas consequências ainda não tinha sido feita. A prática se antecipou à reflexão sobre a ideia de proteção ambiental. Assim, se tu tomas o problema da Mata Atlântica e o nível de desmatamento, tu dizes: - bom, foi um mal necessário! Mas esse mal necessário, que vigorou no litoral do Paraná sobretudo entre 1982 e 87, 88, quando nós chegamos lá, ele produziu uma série de efeitos perversos para quem vivia nesses lugares. E mesmo os técnicos do IAPAR, por exemplo, que eram bastante progressistas e já tinham uma certa visão das coisas, eles já queriam dialogar com os agricultores, mas a lei da APA não permitia

Então tu dizes: - esse mal necessário era um mal necessário! Só que talvez ele não seria necessário se tivéssemos agido contra quem verdadeiramente produz o desmatamento, que são esses trogloditas latifundiários, grandes latifundiários e os responsáveis pela grilagem da mata. E aí a tese do Lovois mostra bem tudo isso, dos fins éticos por trás dos mecanismos de proteção ambiental cujos 
efeitos perversos foram enormes. Então, primeiro, tu acabas tendo um pequeno agricultor que vai desmatar mais a mata do que antes porque ele tem que compensar as proibições que vem com a legislação ambiental e a ação repressora dos órgãos ambientais. E, segundo, tu vais ter pequenos agricultores que vão trabalhar para os grandes latifundiários e palmiteiros clandestinos, porque assim eles ganham mais do que o pouquinho que eles ainda deixam eles plantar e por aí vai.

No caso das APAs vi muito esses conflitos entre populações que viviam no lugar onde viviam, a maioria já a gerações, e que se apropriavam dos recursos sem destruí-los - até porque é só você olhar o grau de preservação que tem no litoral do Paraná, na Amazônia, no Cerrado etc. - e atores de fora que chegavam, desmatavam e entravam em conflito com essas populações ou então acabavam aliciando elas e usando elas como mão de obra barata. Mas também o Estado ajudou a gerar esses conflitos, porque sob vários pontos de vista esses grupos não são só vítimas dos grande proprietários que varrem tudo, são vítimas do Estado, um Estado que não tem competência para conduzir um processo de desenvolvimento alternativo que, ok!, garanta preservação, mas que também respeite o direito dessas pessoas e não reproduza, não compactue com a violência histórica que elas sofrem.

Por outro lado, essa situação foi evoluindo e acho que hoje esses conflitos ambientais já são objeto de muitos estudos, ou seja, há um interesse maior e consequentemente uma maior visibilidade. Hoje é mais difícil você forçar um caiçara, um ribeirinho, um colono a sentar nu num formigueiro. Pode até acontecer, mas está mais difícil. Até saiu um livro do Henri Acselrad lá no Rio de Janeiro sobre conflitos ambientais no Brasil. Além disso, tem aumentado a participação dos antropólogos - que acho que foi importante porque já vinham com uma discussão, com uma reflexão forte sobre as áreas indígenas - e que têm cada vez mais se motivado a trabalhar com populações tradicionais, porque na maior parte das vezes os conflitos e a criação dessas áreas protegidas acontecem em cima das terras de quilombolas, ribeirinhos, caiçaras.

Então esse início foi evoluindo e acho que no Ministério do Meio Ambiente há uma sensibilidade grande para essas questões, acho que a Marina [Silva] deu uma contribuição importante. Inclusive tem havido uma relação proveitosa entre o Ministério do Meio Ambiente e o Desenvolvimento Agrário, porque eles conceberam juntos um novo modelo de reforma agrária na Amazônia e que leva em conta suas especificidades territoriais. Por exemplo, os ribeirinhos que estão na beira do rio tinham 500 $\mathrm{m}^{2}$ em linha reta quando o rio que usam de estrada e onde pescam e vivem faz um monte de curvas. Então a pergunta deveria ser: quais são e como os recursos podem ser explorados e reproduzidos por eles? Disso houve todo um trabalho e hoje tu tens um modelo onde a reforma agrária na Amazônia não é mais a do Rio Grande do Sul. Isso eu considero um esforço necessário e foi muito proveitoso entre um ministério que se ocupa de executar a reforma agrária e redistribuir terras e um ministério que atribui à proteção prioritariamente às áreas de preservação.

Por outro lado, acho que evoluiu positivamente também pela transformação governamental, com a Marina Silva e com o Miguel Rossetto, que fizeram um esforço muito grande. E ao mesmo tempo a Secretaria de Agricultura Familiar do MDA, com o Valter Bianchini, que sempre teve essa linha de preocupação com as produções alternativas, agroecológicas, de buscar selo de qualidade e que também 
ajudou através do Pronaf [Programa de Fortalecimento da Agricultura Familiar] os agricultores extrativistas, os ribeirinhos, as mulheres agricultoras. Houve também uma certa confluência entre MDA e [Ministério do] Meio Ambiente no tratamento e nas políticas para os quilombolas, que de certa maneira foram contemplados com políticas públicas, além é claro da necessidade de defender suas terras e garantir que não sejam expulsos dessas áreas.

Acho que essas questões merecem um estudo adequado, mais profundo do que se tem que fazer com essas novas políticas inclusivas. Agora, evidentemente que, sobre toda essa discussão sobre proteção ambiental, eu diria assim, como vou dizer, assim como tem espécies oportunistas em ecologia vegetal, tem atores sociais oportunistas. Por exemplo, na análise que a gente fez dessa evolução da APA, os agricultores foram grilados, os pequenos, eles dizem: - nós estávamos no morro e nos grilaram e botaram para baixo; depois, de baixo nos grilaram e botaram para cima e agora nós estamos é dentro d'água porque não tem mais para onde nos empurrar! Só que essa pressão inicial, Cleyton, acho que ela foi sendo mais abrandada, os técnicos de certa maneira evoluíram, muito também porque a atuação crítica e a sensibilidade dos movimentos sociais trouxeram à público todos esses conflitos. Então acho que aí tem dois viéses, dois enfoques: o enfoque das populações tradicionais, que são muito apoiadas pelos antropólogos, sociólogos; e o viés da proteção da natureza, levado adiante por ecologistas e pesquisadores que tem realmente uma cabeça que é realmente a de salvar o que ainda se pode salvar.

Só que tu vês bem que esse cinturão, esse escudo de áreas de preservação com o homem podendo viver vai subindo para a Amazônia, até o Tocantins, o Acre etc. E aí há muitas opiniões, mesmo os economistas progressistas, por exemplo, chegam e dizem que isso é muito difícil, que áreas tão grandes sejam todas bloqueadas. A Amazônia tem que ter um desenvolvimento sustentável, mas tem que praticar esse desenvolvimento através de atividades que sejam rentáveis. E realmente, e aí é uma situação muito difícil, porque quando tu analisas o escudo que está se criando, tu vês que a estratégia do Ministério do Meio Ambiente foi de tentar salvar o que dá para salvar, em termos de Amazônia e centro-oeste. Porque o cerrado está completamente destruído, o cerrado hoje em dia, se tu fores lá para dentro dele, é só soja. E a biodiversidade do cerrado que era vista, assim, como uma biodiversidade menor, hoje se sabe que é extremamente rica e importante ecologicamente falando. Mas o que quero dizer é que agora a luta tem que ser contra quem realmente destrói a natureza, quem de fato desmata e acaba com tudo, contra o empresário que passa o correntão, que é aquele troço hediondo que usam para limpar o cerrado, contra os grandes madeireiros e interesses privados e oportunistas que exploram descomedidamente a Amazônia e que põem fogo na floresta e tudo abaixo. Mas é preciso que também lutemos contra tudo isso que a gente sabe sobre os assassinatos de lideranças, sobre a perseguição de movimentos sociais, sobre a ação dos grileiros em cima de posseiros e ribeirinhos e etc. e etc.

Então eu acho, e admito que hoje estou um pouco afastada dessa questão, mas eu acho que tem que se criar mais áreas protegidas, porque de fato é um dos únicos meios que temos para diminuir minimamente o desmatamento total e que está indo numa velocidade enorme. Só que ao mesmo tempo essas áreas têm que incluir novas ideias baseadas em modelos alternativos de desenvolvimento, modelos que favoreçam a população local. Por outro lado, 
é preciso combater os madeireiros de Goiás ou os madeireiros internacionais que estejam livremente arrancando tudo o que podem, como no caso da Aracruz agora aqui no Rio Grande do Sul. Já degradaram as fronteiras agrícolas, o Espírito Santo e estão indo ainda mais longe, porque com o eucalipto começou um novo ciclo que não é mais o das monoculturas tradicionais, soja, gado etc. Agora é um ciclo arbóreo, e não só arbóreo, um ciclo transgênico arbóreo. Então eu acho que a criação de áreas protegidas é necessária, sim, mas tem que haver juntamente com isso uma reflexão profunda sobre como criar outros mecanismos que barrem quem de fato desmata, quem contamina os rios, a terra, o ar e quem envenena a vida das pessoas. E aí um cenário ideal - mas que precisa ser buscado, precisamos lutar nessa direção - seria que todos nós que trabalhamos com essas questões e temos um posicionamento crítico em relação a elas pudéssemos, juntamente com quem mais sofre com a destruição de nossos biomas, ou seja, as populações que neles vivem, ter acesso aos gabinetes, às instâncias de poder, de decisão para poder dizer: - olha, as dificuldades são essas e essas e essas; propomos isso, isso e isso.

(Ai entramos na questão do papel do pesquisador especificamente, claro que não há uma separação nítida, mas o papel das pessoas que estão dentro da ciência, seja ciências sociais ou ciências naturais?) Eu acho, e aí Cleyton, te falei daquela minha nova elaboração sobre ciência cidadã, que na verdade é velha, mas que não estava muito bem elaborada e formalizada. Acho que um pesquisador não perde seu rigor se desenvolver seu trabalho junto com a população local, se ele lutar para ver o encontro entre o saber local e o saber científico, porque isso tudo dá elementos para se ter resultados que se aproximam mais da realidade. Por isso é que cada vez mais é preciso, por um lado, estreitar essa relação dos técnicos com a população local e, por outro, buscar aproximar a política da natureza. Não é possível continuar querendo pensar numa natureza que fique fora do mundo das pessoas, fora das relações de poder, isso é, no mínimo, uma ingenuidade muito grande. O que é um parque nacional se não o resultado de uma política pública? Não é?

Então, sim, temos que produzir resultados de pesquisa, temos que construir conceitos, noções, ferramentas analíticas, mas que não seja uma pesquisa, digo assim, entre aspas, "muito acadêmica", no sentido de fechada em si mesma, porque esse tipo de ciência exclui novas modalidades de trabalhar com as populações. Também, no caso dos sociólogos e dos antropólogos, certos antropólogos, talvez a maioria, que trabalham com as populações locais, eles ficam muito presos ao micro e aí, claro, eles aprofundam bem as questões. Mas precisa mais do que isso, além do rigor dos resultados da nossa pesquisa, que são imprescindíveis, claro.

Além disso, temos que ter uma preocupação com a transformação da nossa linguagem científica e rigorosa em uma linguagem tão científica e tão rigorosa quanto, mas que permita que se dialogue com os saberes e a compreensão daqueles com quem a gente trabalha. Pesquisas que permitam o encontro entre aquilo que obtivemos como resultado e o que eles produzem a partir de um outro tipo de elaboração do saber, quer dizer, um encontro dos saberes entre as duas comunidades que resulte em algum tipo de troca. E é por isso que a nossa linguagem precisa ser acessível, porque não adianta as bibliotecas estarem ali cheias de teses, as revistas cheias de artigos, os pesquisadores com seus lattes cheios de publicações em revistas classe A do MEC, se esse país não muda. Nós somos atores da 
mudança, aliás, nós devemos [dito com ênfase] ser atores da mudança. E há na universidade brasileira - e tenho percorrido esse Brasil afora -, há preconceitos incríveis sobre o que chamam de "pesquisa aplicada”. Dizem: - há! nós não fazemos pesquisa aplicada! Como diz o [Marcel] Jollivet, não se trata de pesquisa aplicada, a pesquisa é finalizada, quer dizer, ela tem uma direção, e a direção sou eu e o meu motivo, tenho uma posição de cidadão e vou ao encontro dessa problemática para expressar o meu papel de pesquisador cidadão. E hoje tem muita gente trabalhando diferente, por exemplo parte do pessoal que trabalha na Amazônia e que tem desenvolvido uma preocupação grande com as comunidades, com pesquisador enterrado lá nos recantos mais longínquos da floresta mas que faz uma discussão de ponta ao mesmo tempo em que dialoga e trabalha junto com a comunidade que estuda.

(Tem gente que vê uma incompatibilidade mais metodológica, como você falou, que estabelece essa distinção do conhecimento científico; dai minha próxima pergunta: como você vê a interface entre essas formas diferentes de conhecimento, de perceber o mundo e de explicar o mundo, entre um conhecimento mais sistematizado vindo da academia e os outros conhecimentos das populações locais? Porque muitos cientistas criticam o engajamento de outros cientistas com as pessoas com quem eventualmente possam estar trabalhando). Acho assim, que existem duas condições para, digamos, a gente poder se transformar num pesquisador cidadão, que é em primeiro lugar fazer muito trabalho de campo, conviver, conviver e conviver. Não é ir lá e fazer enquete ou meia dúzia de entrevistas e voltar para a universidade, voltar para sua casa. Isso não é conviver. Em segundo lugar, esse conviver ao mesmo tempo não é só o conviver, mas é procurar mostrar para as pessoas, com o máximo de sinceridade possível, qual é a nossa preocupação, o que queremos exatamente ao nos aproximarmos delas. É preciso deixar nosso interesse muito claro para evitar decepções e brigas no futuro. Ao mesmo tempo, é preciso que incorporemos, que adotemos como uma de nossas intenções mais fundamentais a preocupação de que eles possam expressar as suas próprias preocupações e que tenham liberdade de intervir, criticar ou mudar mesmo as nossas próprias premissas. Que haja um tipo de comunicação onde abrimos a guarda para que quem a gente estuda possa apontar com o dedo algum preconceito que trazemos conosco. Só assim é que será possível, digamos, juntar os objetivos.

Mas também é fundamental que se busque o encontro - que pode até ser desencontro, não importa, pois mesmo assim algo se aprende -, o encontro de diferentes disciplinas no trabalho. Porque se estou trabalhando com uma problemática ligada à discussão sobre meio ambiente e elejo como objetivo fundamental a proteção da biodiversidade e paro por aí, eu não vou muito longe. Agora, é diferente se parto do pressuposto de que a proteção da biodiversidade não é, digamos - e eu não queria dizer essa palavra -, não é superior a necessidade de garantir a reprodução social e o direito de grupos minoritários que têm sido historicamente explorados. E o contrário também, quer dizer, que também esses direitos e a reprodução social devem sempre prevalecer diante da necessidade de proteção da natureza, dizendo que posso ter toda a devastação do mundo, toda degradação do mundo em nome dos pobres, toda aquela desculpa de que os pobres precisam viver e comer e que por isso precisa conservar o trabalho deles, precisa deixar fazer o que quiserem, entendeu? Se a gente não aceita como já 
dado nem esse lado e nem o outro, uma discussão mais proveitosa pode começar.

Claro, é difícil fazer isso tudo sozinho, ainda mais quando se trata de integrar dinâmicas sociais e naturais e fazer os diferentes conhecimentos sobre elas conversarem. Por isso que acho que a própria problemática, em função da situação em que a gente se encontra, nos leva a chamar para o diálogo outros especialistas. Especialistas que teriam que se dar às mãos por um diálogo mais produtivo e trabalhar juntos no campo, por exemplo: um antropólogo e um agrônomo trabalhando junto com um ecólogo; um sociólogo com um agrônomo trabalhando junto com um jurista ou especialista do direito. E aí vem algo mais do que central, que pode unir interesses diversos, que é a questão da terra no Brasil. Essa para mim é uma questão fundamental, a questão fundiária ligada ao modo de apropriação do território brasileiro. Afinal, tu vês, uma propriedade de $10 \mathrm{mil}$ hectares pode estar nas mãos de uma multinacional ou de um político latifundiário da bancada ruralista, por exemplo, podem também ser inundada para construir bizarras hidrelétricas ou fazer toda aquela meleca que vem com a plantação de eucalipto ou a mineração de ferro etc. Mas esses mesmos 10 mil hectares podem ser destinados para assentamentos da reforma agrária, podem ter sido desapropriados para demarcação de uma terra indígena, de um quilombo, de uma reserva extrativista e, por que não, quem sabe destinado a virar um mosaico de unidades de conservação que inclua, entre as categorias, áreas de proteção integral na forma de parque ou estação ecológica. Viste? Se a gente coloca dessa maneira, aí, ó!, fica claro quem é o inimigo, não é?

Mas também não é só a questão fundiária em si, e sim tudo o que ela implica em termos de relações de poder, questões de vizinhança, a questão do parentesco, os atravessadores, o tipo de ecossistema, que espécies têm lá, o tipo de uso dos recursos, enfim, são tantas as questões, mas no final todas elas chegam na terra e o que fazer com ela. Então todas essas várias questões elas se entrelaçam mesmo num quadradinho pequeno de terra e eu acho que o ideal seria sempre buscar fazer um trabalho que seja interdisciplinar, com cientistas da área do social e da área do natural. Só que isso envolve construir toda uma metodologia que, evidentemente, é exigida por este tipo de temática. Claro, há situações em que isso não é tão necessário, não quero aqui dizer que se deve abolir ou substituir a pesquisa de base, não é por aí. A questão é saber que a realidade é complexa, ou seja, há uma complexidade por trás dessas relações, por exemplo, a discussão sobre comunidades tradicionais, se é tradicional ou se não é tradicional, quer coisa mais complexa que isso? Enfim, o que a gente tem que se dar conta é que por trás disso tudo, por trás da produção do conhecimento científico está um problema de natureza maior, que é um problema de natureza política e, para o pesquisador e o que ele faz fora da academia, um problema de natureza ética, de pensar o que a gente quer mudar no mundo em que a gente vive e que tipo de mundo queremos construir no futuro.

Magda Zanoni, 3 de outubro de 2006. 